\title{
Bilaterality and Symmetry of C-Shaped Mandibular Second Molars in a Mexican Maya and Non-Maya Population: A CBCT in vivo Study
}

\author{
Bilateralidad y Simetría de los Segundos Molares Mandibulares en Forma de C \\ en una Población Mexicana Maya y no Maya: Estudio in vivo Mediante CBCT
}

Elma María Vega-Lizama ${ }^{1}$; Esteban Alexis Morales-Ortega ${ }^{1}$; Marco Ramírez-Salomón ${ }^{1}$ \& Andrea Cucina ${ }^{2}$

VEGA-LIZAMA, E. M.; MORALES-ORTEGA, E. A.; RAMíREZ-SALOMÓN, M. \& CUCINA, A. Bilaterality and symmetry of cshaped mandibular second molars in a Mexican Maya and non-Maya population: a CBCT in vivo study. Int J. Morphol., 39(2):455-462, 2021.

SUMMARY: The objective of this study was to evaluate the bilaterality and symmetry in C-shaped mandibular second molars in Mexican Maya and non-Maya populations using cone-beam computed tomography(CBCT). Five-hundred-twenty-five CBCT scans of patients with left and right mandibular second molars were analyzed to determine the prevalence and bilaterality. The teeth were assessed for the presence of C-shaped root canals, according to Fan et al. (2004) criteria. The sample was subdivided by ethnicity, sex, unilateral/bilateral presence, side of the longitudinal groove, and the $\mathrm{C}$-shaped root canal configuration and symmetry, at the cervical, middle, and apical crosssections of the root. C-shaped mandibular second molars were present in $24.95 \%$ of the individuals. Most (60.30\%) of those showing this trait had it bilaterally. When comparing by ethnicity, sex, and side, we detected no significant differences. The vast majority (97.33 \%) presented the groove along the lingual side. The $\mathrm{C} 3$ was the most prevalent configuration in the overall sample, while in the Maya group, the $\mathrm{C} 1$ was the most common configuration. When analyzed by sex and ethnic group, the non-Maya females tended to deviate from the other groups in terms of bilaterality. Overall, $55.70 \%$ of bilateral C-shaped mandibular second molars were also symmetric in the three radicular thirds. The prevalence of C-shaped mandibular second molars was similar to that reported for northernAsian populations, which is consistent with the evolutionary origins of Native American populations. Most of the sample showed bilaterality and half were symmetric. Clinicians must be aware of the ethnic background of their patients and consider the possible variations to do more predictable root canal treatments.

KEY WORDS: Bilaterality; C-Shaped root canal; Mandibular second molars; Maya ethnicity; Symmetry

\section{INTRODUCTION}

Several studies have described the frequency and configuration of the $\mathrm{C}$-shaped root canal in the mandibular second molars in a wide range of populations (Kato et al., 2014; Martins et al., 2019). Different methodologies have been applied since the first clinical reports appeared in the literature (Cooke 3rd \& Cox, 1979) until today's widespread use of tomography (Min et al., 2006; von Zuben et al., 2017; Pawar et al., 2017; Martins et al.). Results indicate a strong correlation with the populations' ethnic background (Kato et al.; von Zuben et al.). Anthropologically speaking, there are many ways to classify populations; the criteria for ethnicity-related background vary from the geographical place where the individuals were born, last names that are typical of a certain population, and speaking native languages (Scott \& Turner, 1997).
Previous studies indicate that the northeastern Asian population present the higher frequency of occurrence of Cshaped mandibular second molars (Jin et al., 2006; Kim et al., 2016; Ren et al., 2020; von Zuben et al.), with values as high as $40 \%$ and above (Jin et al.; Kim et al.; Ren et al., 2020), while European (Caucasic) populations manifest the lower frequency (Kato et al., 2014, von Zuben et al.). The native Mexican population belongs to the Sino-American (mongoloid) group because it presents dental features that were similar to the northeastern Asia populations (Scott \& Turner). Previous studies have reported C-shaped mandibular second molars frequencies ranging between $30 \%$ and $35 \%$ (Cucina et al., 2008; Ramírez-Salomón et al., 2014) in Southeast Mexico, while von Zuben et al. reported $14.2 \%$ in the central highlands of Mexico. Another study reported

${ }^{1}$ Facultad de Odontología, Universidad Autónoma de Yucatán, Calle 61-A No. 492-A, Centro. C.P. 97218. Mérida, Yucatán, México.

${ }^{2}$ Facultad de Antropología, Universidad Autónoma de Yucatán, Km 1 Carretera Mérida-Tizimín, Cholul. C.P. 97305. Mérida, Yucatán, México. 
VEGA-LIZAMA, E. M.; MORALES-ORTEGA, E. A.; RAMíREZ-SALOMÓN, M. \& CUCINA, A. Bilaterality and symmetry of c-shaped mandibular second molars in a Mexican Maya and non-Maya population: a CBCT in vivo study. Int J. Morphol., 39(2):455-462, 2021.

$39.1 \%$ C-shape root canal configuration in the mandibular firsts premolars in groups from Southeast of Mexico (VegaLizama et al., 2018).

Despite a general knowledge on C-shaped mandibular second molars in different populations, very little is known about the extent of bilaterality or inner structure symmetry (Zheng et al., 2011), which might be helpful information for correctly planning and executing the root canal treatment. Therefore, this study aimed to report the bilaterality and symmetry of the C-shape mandibular second molars in a southeastern Mexican population with a Maya SinoAmerican ethnicity (based on the individuals' last name(s) in comparison with a local non-Maya group).

\section{MATERIAL AND METHOD}

Seven-hundred-eighty-eightimages were obtained from Cone Beam Computed Tomography (CBCT) examinations performed between January 2015 and December 2019 at the Radiology Department of the Dental School of the Universidad Autónoma de Yucatán (UADY). UADY's Medical Ethics Committee approved this study. All the CBCT scans were taken as part of the diagnosis and treatment plan of patients who required different kinds of surgical procedures and were analyzed retrospectively by two of the authors (EMVL and EAMO) from January 2020 to October 2020. Therefore, the reasons for CBCT were independent of this study. Nonetheless, all patient signed a consent form to allow the use of their clinical data for academic purposes without compromising their confidentiality. The senior author is an experienced endodontist (EMVL) with a doctoral degree in root canal morphology; she calibrated one of the authors (EAMO), and both independently recorded the information. All the available tomographic images in which both mandibular second molars were visible were selected, for a total of 525 specimens. All mandibular second molars that allowed a clear reading of their anatomy were included. Alongside this, 15 more CBCT scans were used, which presented only one mandibular second molar with a C-shaped configuration; these 15 images were not used to calculate the overall frequency of occurrence but were included in the tooth-based analysis of the variability of the C-shape's inner structure. Exclusion criteria were the following: teeth with previous endodontic treatments, teeth with immature or resorbed apices, and teeth with restorations that made proper evaluation impossible.

The interrater reliability Cohen kappa test was performed twice. First, 80 CBCT scans $(10.15 \%$ of the total sample) were used to calculate the presence/absence of a Cshaped root canal. The two observers evaluated separately the same 80 CBCT scans (160 teeth). The result of kappa was $\mathrm{K}=$ 1 (total agreement) for the 160 mandibular second molars. Second, for the C-shape classification were used 27 teeth (12 $\%$ of the final sample) with the presence of C-shaped root canal. In total were included 81 observations (because of the three root canal levels) and the kappa was 0.94 with a very good confidence interval ( $\mathrm{IC}=0.810-0.985)$.

The cone-beam computed tomography images were obtained using a CBCT scanner (17-19 iCATÒ Imagining System,Spain) at $120 \mathrm{kV}$ and $5 \mathrm{~mA}$ with an exposure time of $26.9 \mathrm{~s}$, a $16 \mathrm{~cm} ¥ 13 \mathrm{~cm}$ field of view, voxel size of 200 $\mu$ mand coupled to an iCAT VisionÒ(Spain) software. An experienced radiologist performed the acquisition process according to the manufacturer's recommended protocol with the minimum exposure necessary for adequate image quality. The number of roots and root canal configurations were determined in each tooth by moving the cursor to the Z-axis in three planes (coronal, sagittal, and axial).

The C-shaped root canal configurations were assigned according to Fan et al. (2004). The classification of the C-shape configuration was evaluated at cervical (2 $\mathrm{mm}$ apical to the canal orifices in the chamber floor), middle (the middle of the root), and apical ( $2 \mathrm{~mm}$ above radiographic apex) axial levels. The qualitative and quantitative features that characterize the roots and root canals were observed and recorded. Bilaterality was defined as the presence of both mandibular second molars (right and left) with a Cshaped configuration and symmetry when the cervical, middle, and apical cross-sections had the same configuration in both left and right sides.

The collection was sorted by sex and by ethnicity. In this case, the last name was used; we considered as belonging to the Maya group all those individuals who had at least one Maya last name (in Mexico every person adopts the first last name of both parents). On the contrary, all those individuals with more general Mexican, but not Maya last names were assigned to the non-Maya group. Overall, 525 individuals were considered; 161 fell into the Maya category (95 females and 66 males) and 364 in the non-Maya group (240 females and 124 males). The age ranged from 15 to 68 years, with a mean of 37.73 years.

The database was processed in an Excel® worksheet, and the frequencies and statistical analyses were calculated using Statistica 13.5 package (TIMCOß). Chi-squared (X2) and Fisher's exact tests were used to analyze the differences between independent groups. Fisher's exact test was preferred over the X2 when the sample size was reduced.A $\mathrm{P}<0.05$ was considered significant with a $95 \%$ confidence interval. 


\section{RESULTS}

Of the 525 individuals who presented both left and right mandibular second molars, 131 had at least one of them with a C-shaped root canal configuration, against 394 without a C-shape, with a total individual frequency of $24.95 \%$. With regards to the ethnic group, 38 of the Maya group had a C-shaped molar $(38 / 161,23.60 \%)$, compared to 93 individuals from the non-Maya group (93/364, $25.54 \%$ ). This was not statistically significant $(X 2=0.226,1$ d.f., $p=$ $0.6345349)$.

Maya females manifest the C-shaped molar in 25.26 $\%$ of the cases (24/95), and their male counterparts in 21.21 $\%$ of the cases (14/66). Among the non-Maya group, 25.83 $\%$ of females (62/240) and $25.00 \%$ of males (31/124) had a $\mathrm{C}$-shaped molar. Also, in this case, a Chi-squared test did not return a significant result $(\mathrm{X} 2=0.5976,3$ d.f., $\mathrm{p}=$ $0.896988)$.

Of the 131 individuals, 79 presented bilaterality $(60.30 \%)$ and $52(39.70 \%)$ only manifested one molar with a $\mathrm{C}$-shape, and the other was normal. Fifteen additional CBCT scans were added to the study because they presented only one second molar with a C-shaped configuration; the contralateral had been lost (Table I). These fifteen extra teeth were not considered for the issue of symmetry or asymmetry but were considered when individual tooth analyses were performed. Overall, 45 individuals were males and 86 females (plus four "unique" males and 11 "unique" females).

As mentioned above, this anatomic condition was mostly bilateral when the whole sample was considered. However, differences can be appreciated by sex with a slightly higher frequency of unilaterality in males, and a markedly higher frequency of bilaterality in females. A significant difference was observed in the unilateral versus bilateral distribution of C-shaped second molars (Fisher's exact test, $\mathrm{P}=0.0007)$. When data were presented by ethnicity, $75.00 \%$ of Maya females and $69.35 \%$ of non-
Maya females were bilateral; $32.25 \%$ of non-Maya males were bilateral in comparison with $57.14 \%$ of Maya males (Table II).

Table II. Number and frequency of C-shape mandibular second molars based on sex, ethnicity and laterality.

\begin{tabular}{|c|c|c|c|c|c|c|c|}
\hline & \multirow{2}{*}{\multicolumn{2}{|c|}{ Bilateral }} & \multicolumn{4}{|c|}{ Unilateral } \\
\hline & & & & Left & & Rigth & \\
\hline & & $\mathrm{n}$ & $(\%)$ & $\mathrm{n}$ & $(\%)$ & $\mathrm{n}$ & $(\%)$ \\
\hline \multirow{2}{*}{ Males } & Maya & 8 & 10.13 & 3 & 13.04 & 3 & 10.34 \\
\hline & Non-Maya & 10 & 12.66 & 7 & 30.43 & 14 & 48.28 \\
\hline \multirow{3}{*}{ Females } & Maya & 18 & 22.78 & 3 & 13.04 & 3 & 10.34 \\
\hline & Non-Maya & 43 & 54.43 & 10 & 43.48 & 9 & 31.03 \\
\hline & & 79 & 100.00 & 23 & 100 & 29 & 100.00 \\
\hline
\end{tabular}

A Fisher's exact test for bilaterality between Maya and non-Maya males shows no significant differences $(\mathrm{P}=$ 0.1883 ). The same can be said for females based on ethnicity (Fisher's exact test $P=0.792$ ). The comparison by sex-based and ethnicity shows that the Maya group does not differ between sexes (Fisher's exact test $\mathrm{P}=2964$ ); on the contrary, non-Maya individuals show a significant difference between sexes (Fisher's exact test $\mathrm{P}=0.0009$ ). There were no significant differences between sides (left or right) in any combination by sex and or ethnicity. It must be noted, however, that adding more sub-groups, and decreasing the sample size reduce the possibility to reach statistically significant thresholds.

As regards the tooth-based analysis of C-shaped configuration, a total of $225 \mathrm{C}$-shaped molars were analyzed. These were from 79 bilateral individuals, 52 unilateral, and the 15 "unique" individuals for which the contralateral molar was missing. All these teeth presented one root.The Cshaped classification was described in Table III. Overall, we obtained 675 horizontal cross-sections, which correspond to a cervical, middle, and apical one for each of the 225 teeth. A high prevalence of $\mathrm{C} 3$ form $(47.26 \%)$ was observed for the combined sexes (120 males plus 199 females). Onehundred-nineteen-teeth $(52.88 \%)$ presented the same configuration in the three levels.

Table I. Number and frequency of C-shaped mandibular second molars based on sex and laterality.

\begin{tabular}{|c|c|c|c|c|c|c|}
\hline & \multicolumn{2}{|c|}{ Male } & \multicolumn{2}{|c|}{ Female } & \multicolumn{2}{|c|}{ Total } \\
\hline & $\mathrm{n}$ & $(\%)$ & $\mathrm{n}$ & $(\%)$ & $\mathrm{n}$ & $(\%)$ \\
\hline Bilateral* & 18 & 40.00 & 61 & 70.93 & 79 & 60.30 \\
\hline Unilateral $* *$ & 27 & 60.00 & 25 & 29.07 & 52 & 39.70 \\
\hline Total & 45 & 100.00 & 86 & 100.00 & 131 & 100.00 \\
\hline Unique $* * *$ & 4 & & 11 & & 15 & \\
\hline
\end{tabular}

* Both right and left molars with C-shape. ** One side with $\mathrm{C}$-shape and the other side without a C-shape. *** The individual presented a second molar with C-shape, but the contralateral was missing. They were not included in the overall frequencies. 
When compared by general configuration (regardless of the position along the root), highly significant differences were detected between Maya and non-Maya groups regardless of sex (X2 41.3569, 3 d.f., $\mathrm{P}=0.0001)$. When comparing sexes (males versus females), the Maya sample had no significant differences (X2 3.9072, 3 d.f., $\mathrm{P}=$ 0.27166), while the non-Maya sample did (X2 18.0399, 3 d.f., $P=0.000432$ ). In the comparison by sex and ethnicity, both males and females present highly significant differences between Maya and non-Maya groups (respectively X2 $18.1167,3$ d.f., $\mathrm{P}=0.000416$ for males, and X2 26.5267, 3 d.f., $\mathrm{P}=0.00001$ for females).

Figure 1 shows the percent distribution of the absolute values described in Table III for the cervical, middle, and apical cross-sections in the four sub-groups. Again, were observed that the $\mathrm{C} 3$ form was usually the most frequent. However, it was interesting to note that both male and female Maya people presented a C1 configuration consistently higher than in the non-Maya group. The $\mathrm{C} 2$ form was generally low, as well as the $\mathrm{C} 4$, though the latter was higher in the female non-Maya group.

Table IV presents the extent of symmetry of bilateral C-shaped second molars in the 79 CBCT scans by sex and ethnicity. Symmetry prevails in non-Maya females with 26 out of 43 individuals $(60.46 \%)$; all the other cases present an equal distribution between sexes. However, this difference does not reach the alpha 0.05 significance thresholds in any comparison.

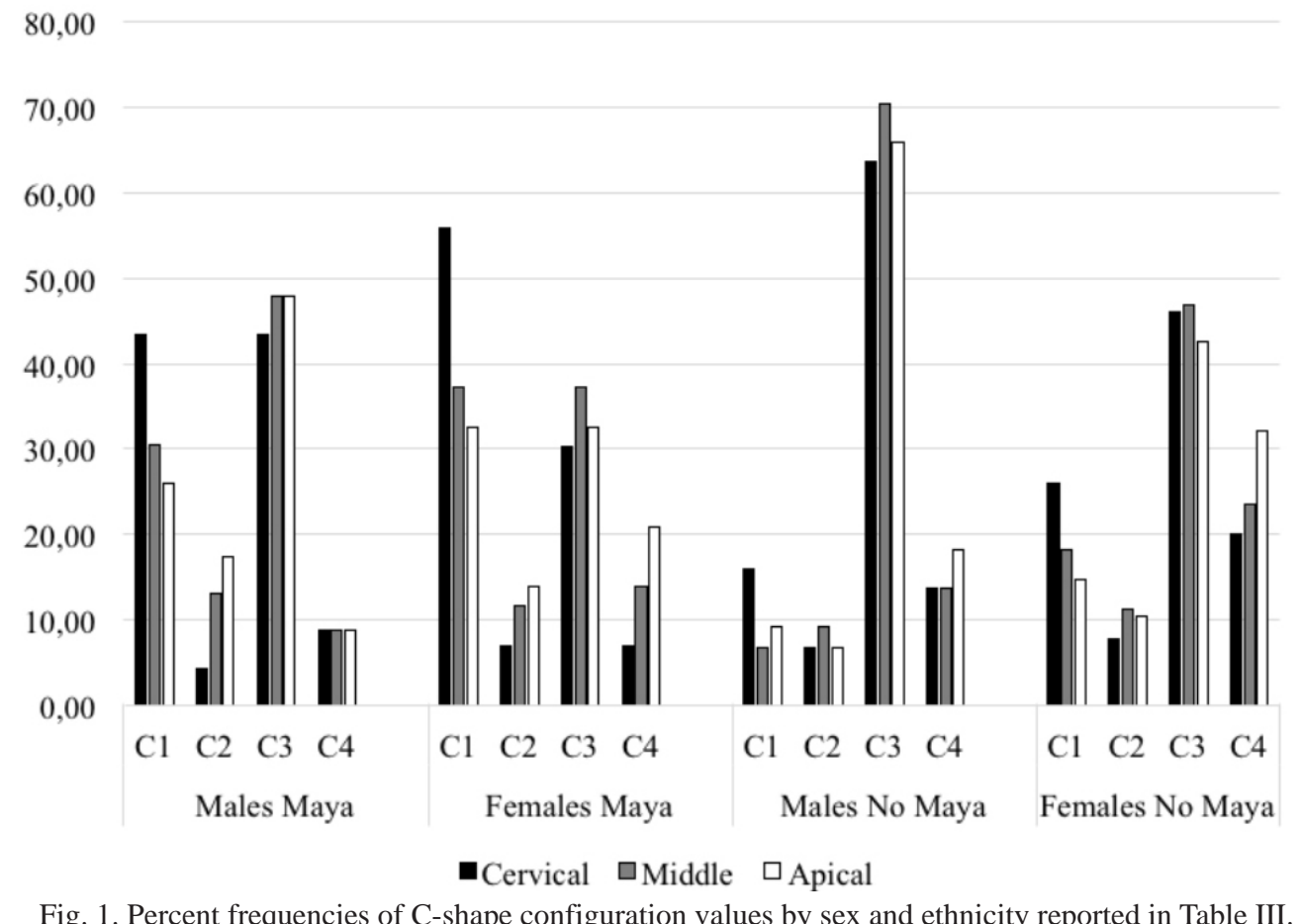

Table III. Number and frequency of C-shape mandibular second molars classification based on sex and ethnicity.

\begin{tabular}{llcccccccc}
\hline & & \multicolumn{3}{c}{ Males } & \multicolumn{5}{c}{ Females } \\
& & $\mathrm{C} 1$ & $\mathrm{C} 2$ & $\mathrm{C} 3$ & $\mathrm{C} 4$ & $\mathrm{C} 1$ & $\mathrm{C} 2$ & $\mathrm{C} 3$ & $\mathrm{C} 4$ \\
\hline \multirow{2}{*}{ Maya (n = 66 teeth) } & Cervical & 10 & 1 & 10 & 2 & 24 & 3 & 13 & 3 \\
23 Males and 43 Females & Middle & 7 & 3 & 11 & 2 & 16 & 5 & 16 & 6 \\
Total 198 slices & Apical & 6 & 4 & 11 & 2 & 14 & 6 & 14 & 9 \\
Non-Maya (n = 159 teeth) & Cervical & 7 & 3 & 28 & 6 & 30 & 9 & 53 & 23 \\
44 Males and 115 Females & Middle & 3 & 4 & 31 & 6 & 21 & 13 & 54 & 27 \\
Total 477 slices & Apical & 4 & 3 & 29 & 8 & 17 & 12 & 49 & 37 \\
Total 675 slices & & 14 & 10 & 88 & 20 & 68 & 34 & 156 & 87 \\
& & 37 & 18 & 120 & 26 & 122 & 48 & 199 & 105 \\
\hline
\end{tabular}


Table IV. Symmetry of bilateral C-shape mandibular second molars.

\begin{tabular}{clcccc}
\hline & & \multicolumn{2}{c}{ Symmetry } & \multicolumn{2}{c}{ Asymmetry } \\
\hline \multirow{2}{*}{ Males } & $\mathrm{n}$ & $(\%)$ & $\mathrm{n}$ & $(\%)$ \\
& Maya & 4 & 50.00 & 4 & 50.00 \\
& Non-Maya & 5 & 50.00 & 5 & 50.00 \\
\multirow{3}{*}{ Females } & Maya & 9 & 50.00 & 9 & 50.00 \\
& Non-Maya & 26 & 60.46 & 17 & 39.54 \\
& Total & 44 & 55.70 & 35 & 44.3 \\
\hline
\end{tabular}
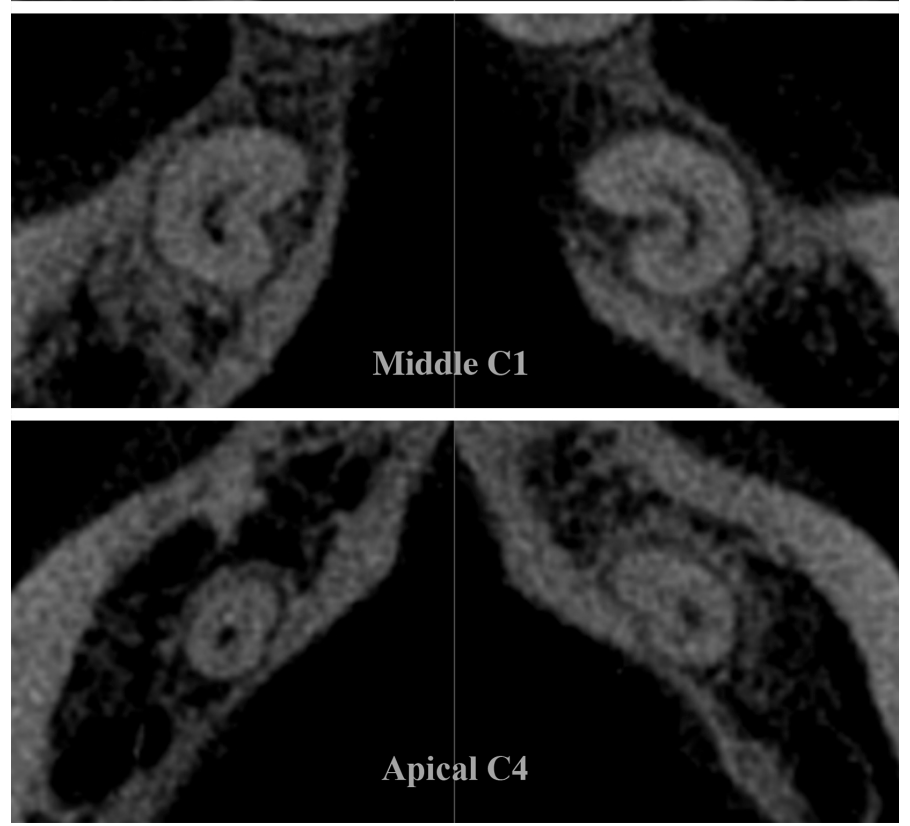

Fig. 2. Composite image of a symmetric root canal configuration at cervical, middle and apex level.
Table V presents the level of symmetry (left and right) in the 79 cases with bilateral mandibular second molars with C-shaped root canal configuration by sex and radicular cross-section. More than half $(55.70 \%)$ had a symmetrical pattern (Fig. 2), and $22.78 \%$ were totally asymmetrical. In this case, no significant difference can be appreciated in both complete symmetries by ethnicity, as well as complete asymmetry. For the mixed asymmetry, individual values were so few and scattered that no pattern can be ascertained, and no statistical analyses were performed.

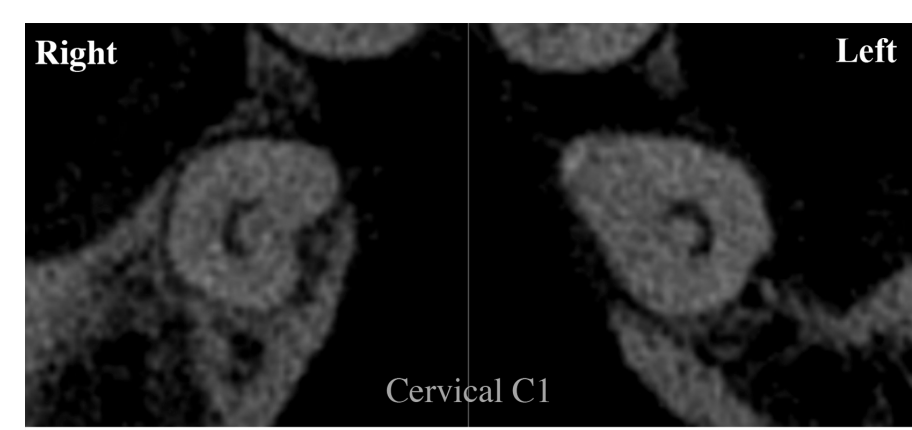

Table V. Level of symmetry of bilateral C-shaped mandibular second molars by radicular third.

\begin{tabular}{|c|c|c|c|c|c|c|}
\hline & \multicolumn{2}{|c|}{ Maya } & \multicolumn{2}{|c|}{ Non-Maya } & \multicolumn{2}{|c|}{ Total } \\
\hline & Males & Females & Males & Females & $\mathrm{n}$ & $\%$ \\
\hline Cervical, middle and apical & 4 & 9 & 5 & 26 & 44 & 55.70 \\
\hline Cervical and middle & 0 & 1 & 1 & 3 & 5 & 6.33 \\
\hline Cervical and apical & 0 & 0 & 0 & 2 & 2 & 2.53 \\
\hline Middle and apical & 0 & 0 & 1 & 0 & 1 & 1.27 \\
\hline Cervical & 1 & 4 & 1 & 1 & 7 & 8.86 \\
\hline Apical & 2 & 0 & 0 & 0 & 2 & 2.53 \\
\hline None & 1 & 4 & 3 & 10 & 18 & 22.78 \\
\hline Total & 8 & 18 & 11 & 42 & 79 & 100 \\
\hline
\end{tabular}

All C-shaped molar manifests a groove in its root. In the 225 teeth analyzed, 219 (97.3\%) presented the groove along the lingual side. Only six molars $(2.66 \%)$ presented the groove along the buccal side of the root, and these six specimens were distributed in five individuals. Specifically, they were two individuals of Maya ethnic origins and three individuals determined as non-Maya. The Maya were: one asymmetric female (i.e., only one tooth was C-shaped), and this tooth presents the groove on the vestibular side, and one symmetric male (both mandibular second molars were C-shaped), and both present the groove on the vestibular side. As regards the three non-Maya individuals, two of them (both females) were asymmetric, and in both the groove was vestibular. The last individual, again a female, was unique, and her (only) mandibular second molar available (the right one) showed the vestibular groove. The extremely reduced number of cases (five individuals for a total of six teeth) limited the possibility to carry out statistical inferences on the vestibular position of the groove. 
VEGA-LIZAMA, E. M.; MORALES-ORTEGA, E. A.; RAMíREZ-SALOMÓN, M. \& CUCINA, A. Bilaterality and symmetry of c-shaped mandibular second molars in a Mexican Maya and non-Maya population: a CBCT in vivo study. Int J. Morphol., 39(2):455-462, 2021.

\section{DISCUSSION}

The present study indicates that the Maya region shows the second-highest frequency after those reported in the north (Jin et al.) and northeastern Asia (Kim et al.; von Zuben et al.). As expected, because of the ethnicity of the present dental collection, values are higher than those reported for southern Asia and other parts of the world (Gulabivala et al., 2001; Kato et al.; Pawar et al.; von Zuben et al.).

Lower values were reported for a sample in Mexico's highlands (von Zuben et al.). The population in Mexico City is highly stratified, and higher education is positively correlated to the European lineage (Lisker et al., 1986). No socioeconomic information was provided for the sample from Mexico's highlands, so it was impossible to make a direct comparison when extrinsic factors might bias the sample. We did know, on the other side, that our Maya and non-Maya collection derives from the low-income strata of the society, because that's the characteristic of the people that attend the University's dental clinics.

As we have seen, the overall frequency of C-shaped molar was $24.95 \%$ without significant differences by sex and ethnicity. This value was slightly lower than the 30-35 $\%$ previously reported for a Maya population (Cucina et al.; Vega-Lizama et al., 2009; Ramírez-Salomón et al.).

As regards sex, previous studies in Korea, Brazil, China, India, Mexico, Portugal, Spain, and Saudi Arabia reported differences between males and females in the general expression of the trait (Zheng et al.; Kim et al.; von Zuben et al.; Alfawaz et al., 2019), with females presenting it more often than males. On the contrary, Pawar et al. and von Zuben et al. reported similarities between sexes in India, England, South Africa, and the United States of America. These latter were in line with our general results; even though Maya females present a slightly higher frequency than Maya males $(25.3 \%$ versus $21.2 \%)$, the difference was not statistically significant.

The most prevalent morphology was the $\mathrm{C} 3$ form (Zheng et al.; von Zuben et al.; Mashyakhy et al., 2020). Results from this study were consistent with those reported in the literature. However, in the Maya group, the $\mathrm{C} 1$ configuration was even slightly more common than the $\mathrm{C} 3$ compared to the non-Maya group. Therefore, the clinicians must expect the $\mathrm{C} 3$ configurations for the non-Maya population, while the $\mathrm{C} 1$ and $\mathrm{C} 3$ for the Maya population. Another study done with an Indian sample (Pawar et al.) reported the $\mathrm{C} 2$ as the more common configuration, so ethnicity should be considered when performing root canals on mandibular second molars.

As for the side of the mandible where the C-shaped molar was similar (left or right), it was in line with the results obtained by Kim et al. on a Korean simple, by Zheng et al. on a Chinese sample, and by von Zuben et al. on several populations worldwide. Only for an English sample, von Zuben et al. reported side differences.

The data on bilaterality were relatively scarce in the literature, which limits the possibility to understand whether ethnicity might play a role in the bilateral expression of this trait. The results in our study $(60.30 \%)$ were similar to the $70 \%$ reported by Kim et al. for a Korean sample and 77.2 $\%$ in the Mexican Southeast, even though the latter used panoramic X-rays instead of CBCT (Ávila-Gómez et al., 2012). However, our results were higher than the $46.2 \%$ in Saudi Arabia (Alfawaz et al.) and lower than the $81.3 \%$ reported by Zheng et al. in a Chinese group. Even though high frequencies of bilaterality seem to characterize populations in northeastern Asia (from which the Native Americans derive), the paucity of data on a worldwide scale imposes great caution in making such inferences.

Last, the results on the side of groove indicate that it occurs in almost $100 \%$ long the lingual side. It was consistent with what was reported for other Asian populations (Zheng et al.; Kim et al.) and differs from that reported by Mashyakhy et al. for a Saudi Arabian population, which shows only the $62.06 \%$.

Overall, comparative analyses suggest that while there was no difference between the Maya and non-Maya groups when the general frequency of occurrence was considered, some differences emerge with non-Maya females in some of the C-shaped dental features. Ethnicity seems to be relevant, because the results from this study match more closely those reported for northeastern Asian populations than for populations from other regions in the world. This was not unexpected, given the Native American population originated from the Sinodont ones (Scott \& Turner). In this perspective, the Maya and non-Maya groups tend to be equally representative of the local population, being both parts of the Mesoamerican population. When making comparisons, however, it is important to take into consideration sample origin and characteristics. As mentioned above, social status was an important factor in shaping a population, because of genetic drift and exogamy/ endogamy effects. Herrera-Atoche et al. (2019) noticed that a sample from the inner territories of the State of Yucatan, of which Merida is the state capital, manifested a series of dental traits whose frequencies were likely the result of 
endogamic factors rather than micro-evolutionary factors. While we were not aware of the characteristics of the comparative samples in the literature, we can ascertain that both our Maya and non-Maya groups belong to the socioeconomically lower segment of the local population, which is likely to be representative of the original Native population.

Overall, the local population manifests more similarities with the recent northeastern Asia population than with other groups worldwide. Nonetheless, it is important to consider the origin of the sample, given that several external factors (like socioeconomic factors) do modify the genetic structure of a group. Hopefully, more studies will be carried out in the future that expand our knowledge about this feature.

\section{CONCLUSIONS}

This study presents novel data on external and internal morphology of the $\mathrm{C}$-shaped mandibular second molar, thus contributing to the literature on asymmetry and bilaterality of this dental trait. The Maya and non-Maya groups analyzed in this study show within-groups homogeneity, indicating a common genetic background within the Mexican population, at least in terms of dental morphology, even though some differences characterize the non-Maya female in comparison with the other sub-groups. Clinicians must be aware of the ethnic background of their patients and consider the possible variations to do more predictable root canal treatments.

\section{ACKNOWLEDGEMENTS}

This research did not receive any specific grant from funding agencies in public, commercial or non-profit sectors. We are grateful to Dr. Mauricio Escoffié Ramírez, Administrative Secretary of the School of Dentistry, for granting access to the School of Dentistry's database. We also thank radiologist Abel José Cauich Hernández for his help in converting images for analysis.

VEGA-LIZAMA, E. M.; MORALES-ORTEGA, E. A.; RAMÍREZ-SALOMÓN, M. \& CUCINA, A. Bilateralidad y simetría de los segundos molares mandibulares en forma de $\mathrm{C}$ en una población Mexicana Maya y no-Maya: estudio in vivo mediante CBCT. Int. J. Morphol., 39(2):455-462, 2021.

RESUMEN: El objetivo de este estudio fue evaluar la bilateralidad y simetría de los segundos molares mandibulares en forma de C en una población Mexicana Maya y no-Maya mediante tomografía computarizada de haz cónico (CBCT).Material and Métodos: Se analizaron quinientos veinticinco tomografías de pacientes con segundos molares mandibularesderecho e izquierdo para determinar la prevalencia y bilateralidad. Los dientes fueron evaluados según la presencia de conductos en forma de $\mathrm{C}$ de acuerdo a los criterios de Fan et al. La muestra fue subdividida por etnicidad, sexo, presencia bilateral/unilateral, lado del surco y configuración y simetría de los conductos en los cortes transversales cervical, medio y apical. Los segundos molares mandibulares en forma de C estuvieron presentes en el $24.95 \%$ de los individuos. La mayoría $(60.30 \%)$ de los que mostraron este rasgo lo hicieron de forma bilateral. El comparar por etnicidad, sexo y lado, no se encontraron diferencias estadísticamente significativas. La gran mayoría (97.33\%) presentó el surco por lingual. C3 fue la configuración más prevalente en la muestra general, mientras que en el grupo Maya el C1 fue la más común. El análisis por sexo y grupo étnico arrojó que las mujeres no Mayas tendieron a desviarse de los otros grupos en términos de bilateralidad. El $55.70 \%$ de los segundos molares mandibulares bilaterales fueron simétricos en sus tres tercios radiculares. La prevalencia de los segundos molars mandibulares en forma de $\mathrm{C}$ fue similar a la reportada para las poblaciones del norte de Asia, lo cual es consistente con los orígenes evolutivos de las poblaciones nativas americanas. La mayor parte de la muestra presentó el rasgo de forma bilateral y la mitad de éstos fueron simétricos. Los odontólogos deben tomar en cuenta el origen étnico de sus pacientes y considerar las posibles variaciones para realizar tratamientos endodónticos más predecibles.

PALABRAS CLAVE: Bilateralidad; Conductos radiculares en forma de $C$; Segundos molares mandibulares; Etnicidad Maya, Simetría.

\section{REFERENCES}

Alfawaz, H.; Alqedairi, A.; Alkhayyal, A. K.; Almobarak, A. A.; Alhusain, M. F. \& Martins, J. N. R. Prevalence of C-shaped canal system in mandibular first and second molars in a Saudi population assessed via cone beam computed tomography: a retrospective study. Clin. Oral Inv., 23(1):107$12,2019$.

Ávila-Gómez, J. A.; Vega-Lizama, E. M.; López-Villanueva, M. E.; AlvaradoCárdenas, G. \& Ramírez-Salomón, M. A. Bilateralidad de segundos molares mandibulares con conductos en c. Rev. Odontol. Latinoam., 4(2):33-6, 2012.

Cooke 3rd, H. G. \& Cox, F. L. C-shaped canal configurations in mandibular molars. J. Am. Dent. Assoc., 99(5):836-40, 1979.

Cucina, A.; Vega Lizama, E.; Ramírez, M., Alvarado Cárdenas, G. \& Tiesler, V. Morphology of root and c-shape canal in prehispanic and modern Maya groups from Northern Yucatan. Dent. Anthropol., 21(2-3):46-9, 2008.

Fan, B.; Cheung, G. S. P.; Fan, M.; Gutmann, J. L. \& Bian, Z. C-shaped canal system in mandibular second molars: Part I--Anatomical features. $J$. Endod., 30(12):899-903, 2004.

Gulabivala, K.; Aung, T. H.; Alavi, A. \& Ng, Y. L. Root and canal morphology of Burmese mandibular molars. Int. Endod. J., 34(5):359-70, 2001.

Herrera-Atoche, J. R.; Ríos-Muñoz, A. M.; Sardaneta-Escudero, D. A.; Colomé-Ruiz, G. E. \& Cucina, A. Anatomical variations of maxillary lateral incisors: A comparative analysis of archaeological and modern populations from the Yucatan peninsula. Homo, 70(2):147-54, 2019.

Jin, G. C.; Lee, S. J. \& Roh, B. D. Anatomical study of C-shaped canals in mandibular second molars by analysis of computed tomography. J. Endod., 32(1):10-3, 2006 
Kato, A.; Ziegler, A.; Higuchi, N.; Nakata, K.; Nakamura, H. \& Ohno, N. Aetiology, incidence and morphology of the C-shaped root canal system and its impact on clinical endodontics. Int. Endod. J., 47(11):1012-33, 2014.

Kim, S. Y.; Kim, B. S. \& Kim, Y. Mandibular second molar root canal morphology and variants in a Korean subpopulation. Int. Endod. J., 49(2):136-44, 2016.

Lisker, R.; Perez-Briceño, R.; Granados, J; Babinsky, V.; de Rubens, J.; Armendares, S. \& Buentello, L. Gene frequencies and admixture estimates in a Mexico City population. Am. J. Phys. Anthropl., 71(2):203-7, 1986.

Martins, J. N. R.; Marques, D.; Silva, E. J. N. L.; Caramês, J.; Mata, A. \& Versiani, M. A. Prevalence of C-shaped canal morphology using cone beam computed tomography - a systematic review with meta-analysis. Int. Endod. J., 52(11):1556-72, 2019.

Mashyakhy, M. H.; Chourasia, H. F.; Jabali, A. H.; Bajawi, H. A.; Jamal, H.; Testarelli, L. \& Gambarini, G. C-shaped canal configuration in mandibular premolars and molars: Prevalence, correlation, and differences: An In Vivo study using cone-beam computed tomography. Niger. J. Clin. Practice, 23(2):232-9, 2020.

Min, Y.; Fan, B.; Cheung, G. S. P.; Gutmann, J. L. \& Fan, M. C-shaped canal system in mandibular second molars Part III: The morphology of the pulp chamber floor. J. Endod., 32(12):1155-9, 2006.

Pawar, A. M.; Pawar, M.; Kfir, A.; Singh, S.; Salve, P.; Thakur, B. \& Neelakantan, P. Root canal morphology and variations in mandibular second molar teeth of an Indian population: an in vivo cone-beam computed tomography analysis. Clin. Oral Investig., 21(9):2801-9, 2017.

Ramírez-Salomón, M.; Vega-Lizama, E.; Tiesler, V.; Alvarado-Cárdenas, G.; López Villanueva, M.; Sierra-Sosa, T. \& Cucina, A. The C-shaped canal molar: an Endodontic-Archaeological study of the relationships between Mayan pre-Hispanic and contemporary population of Yucatán. Int. Endod. J., 47(11):1084-9, 2014.

Scott, R. \& Turner, C. The Anthropology of Modern Human Teeth. New York, Cambridge University Press, 1997.

Vega-Lizama, E. M.; Alvarado-Cárdenas, G.; Ramirez-Salomón, M. A. \& Rueda-Gordillo, F. Prevalencia de conductos en forma de c. Endod. Actual., 4(10):36-44, 2009.

Vega-Lizama, E. M.; Tiesler, V.; Chi-Keb, J. R.; Ramírez-Salomón, M.; Hernández-Mejía, A., \& Cucina, A. Root canal morphology of the mandibular first premolars in a Yucatecan population using cone beam computed tomography: an in vitro study. Int. J. Morphol., 36(4):121621, 2018.

von Zuben, M.; Martins, J. N. R.; Berti, L.; Cassim, I.; Flynn, D.; González, J. A.; Gu, Y.; Kottoor, J.; Monroe, A.; Rosas-Aguilar, R.; et al., Worldwide prevalence of mandibular second molar c-shaped morphologies evaluated by cone-beam computed tomography. $J$. Endod., 43(9):1442-7, 2017.

Zheng, Q.; Zhang, L.; Zhou, X.; Wang, Q.; Tang, L.; Song, F. \& Huang, D. $\mathrm{C}$-shaped root canal system in mandibular second molars in a Chinese population evaluated by cone-beam computed tomography. Int. Endod. J., 44(9):857-62, 2011.

\author{
Corresponding author: \\ Elma María Vega Lizama \\ Calle 44-A No. 232 por 25 y 25 Col. Roma \\ Mérida Yucatán \\ C.P.97218 \\ MEXICO
}

Email: elma.vega@correo.uady.mx

Received: 02-12-2020

Accepted: 29-12-2020 